Review :

\title{
UPAYA PENINGKATAN PRODUKTIVITAS TANAMAN KACANG TANAH DAN PERBAIKAN KESUBURAN TANAH PODZOLIK MERAH KUNING MELALUI PEMANFAATAN TEKNOLOGI BIOCHAR DI SULAWESI TENGGARA
}

\author{
Edi Tando \\ Balai Pengkajian Teknologi Pertanian Sulawesi Tenggara \\ JIn. Prof. Muh. Yamin No. 89 Puuwatu, Kota Kendari, SULTRA 93114 \\ Email : edit.kendari@yahoo.com
}

\begin{abstract}
ABSTRAK
Di Indonesia, saat ini Kacang Tanah (Arachis hypogaea L.) sudah menjadi komoditas penting dan strategis.Kondisi lahan pertanian di Sulawesi Tenggara sebagian besar didominasi oleh tanah Podzolik Merah Kuning. Menurunnya kesuburan tanah merupakan salah satu penyebab rendahnya produktivitas kacang tanah. Tujuan penyusunan makalah yaitu untuk memberikan informasi tentang upaya peningkatan produktivitas tanaman kacang tanah dan perbaikan kesuburan tanah podzolik merah kuning melalui pemanfaatan teknologi biochar di Sulawesi Tenggara.

Pemanfaatan limbah pertanian serta kotoran hewan memiliki potensi besar sebagai biochar atau arang hayati tahan pelapukan di Sulawesi Tenggara. Teknologi biochar memiliki potensi meningkatkan kandungan ketersediaan carbon dalam mampu, memperbaiki kemampuan tanah dalam menahan air dan mengurangi kehilangan unsur hara. Aplikasi teknologi biochar dapat memberikan efek baik melalui perbaikan sifat fisik tanah, biologi tanah dan kimia tanah dengan memasok sejumlah nutrisi yang penting bagi pertumbuhan dan peningkatan hasil panen tanaman kacang tanah.
\end{abstract}

Kata kunci : produktivitas, kacang tanah, kesuburan tanah, biochar

\section{PENDAHULUAN}

Di Indonesia, saat ini Kacang Tanah (Arachis hypogaea L.) sudah menjadi komoditas penting dan strategis (Taufiq dan Kristono, 2015). Tanaman kacang tanah memiliki nilai ekonomi yang tinggi, sehingga termasuk suatu jenis komoditi tanaman pangan yang mengandung protein dan lemak nabati yang tinggi serta dipergunakan sebagai bahan makanan dan bahan baku industri (Raja et al., 2013). Tetapi produksinya masih sangat rendah di Sulawesi Tenggara. Produksi kacang tanah tahun 2014 yaitu $0.46 \mathrm{t}$, masih rendah jika dibandingkan rata - rata produksi kacang tanah secara nasional yaitu 1.87 t (BPS, 2015).

Menurut BPS Sultra (2013) bahwa Provinsi Sulawesi Tenggara memiliki sedikitnya enam jenis tanah, yaitu Podsolik Merah Kuning seluas 2.299.729 ha (60,30\%) dari luas tanah Sulawesi Tenggara, Mediteran seluas 898.802 ha $(23,57 \%)$, Latosol seluas
349.784 ha $(9,17 \%)$, Organosol seluas 116.099 ha $(3,04 \%)$, Alluvial seluas 129.569 ha $(3,40 \%)$

dan Grumosol seluas 20.017 ha $(0,52 \%)$. Kondisi lahan pertanian di Sulawesi Tenggara sebagian besar didominasi oleh tanah Podzolik Merah Kuning atau Ultisol. Penyebab rendahnya produktivitas tanah Podzolik Merah Kuning ialah memburuknya sifat fisik dan kimia tanah karena kadar bahan organik tanah rendah. Lahan kering masam Ultisol memiliki reaksi tanah yang masam, kadar $\mathrm{Al}$ yang dapat ditukar dan fiksasi $\mathrm{P}$ yang tinggi, kandungan bahan organik redah, basa - basa dapat tukar yang rendah, Kapasitas Tukar Kation (KTK) dan Kejenuhan Basa (KB) yang rendah serta aktivitas biologi tanah rendah (Hartatik dan Setyana, 2012).

Menurut Mulyani (2006) bahwa semakin menurunnya kesuburan tanah merupakan salah satu penyebab rendahnya produktivitas kacang tanah. Beberapa hasil penelitian menunjukkan bahwa penurunan kesuburan tanah dapat dipulihkan dengan 
aplikasi bahan organik (Sudiarso, 2007). Pemanfaatan sisa-sisa tanaman hasil panen pertanian, kotoran ternak, kompos dan bokashi dalam bentuk bahan organik ialah suatu upaya meningkatkan kesuburan tanah (Sutanto, 2002). Namun, lingkungan tropis di Indonesia, menyebabkan laju dekomposisi maupun mineralisasi bahan organik berlangsung sangat cepat, berdampak pada penambahan bahan organik setiap musim tanam dalam mempertahankan produktivitas lahan, sehingga mengakibatkan semakin menurunnya efektivitas penggunaan bahan organik untuk produktivitas pertanian serta meningkatnya biaya usaha tani. Suatu alternatif untuk mengurangi laju dekomposisi bahan organik dan pelepasan carbon dari dalam tanah ialah melalui pemanfaatan limbah pertanian maupun kotoran hewan menjadi biochar atau arang hayati tahan pelapukan. (Glaser et al., (2002)

Tujuan penyusunan makalah yaitu untuk memberikan informasi tentang upaya peningkatan produktivitas tanaman kacang tanah dan perbaikan kesuburan tanah podzolik merah kuning melalui pemanfaatan teknologi biochar ramah lingkungan di Sulawesi Tenggara.

\section{PEMBAHASAN}

\section{TANAH PODSOLIK MERAH KUNING}

Tanah Podsolik Merah Kuning Tanah dapat diklasifikasikan sebagai tanah Ultisol. Ultisol merupakan tanah mineral yang telah mengalami perkembangan dari bahan batuan induk tua dan telah mengalami pelapukan lanjut. Tanah Ultisol memiliki tingkat perkembangan cukup lanjut, peningkatan fraksi liat, reaksi tanah yang masam dan kejenuhan basa rendah. Selain itu, tanah Ultisol memiliki warna kuning kecoklatan sampai warna merah. Di Horizon argilik, warna tanah Ultisol memiliki hue yang bervariasi, mulai dari 10YR sampai 10R (nilai 3 - 6) dan kroma (nilai 4 - 8) (Isa et al., 2004; Prasetyo et al., 2005). Tanah Ultisol memiliki nilai kejenuhan basa kurang dari 35\%, hal ini sebagai suatu syarat dalam klasifikasi tanah Ultisol menurut Soil Taxonomy. Selanjutnya, pengklasifikasian tanah Ultisol berdasarkan data analisis dari berbagai wilayah menunjukkan bahwa tanah Ultisol didasarkan pada sumber atau jenis bahan induk penyusunnya misalnya batu liat maupun batu pasir. Ultisol memiliki kelas besar butir bervariasi, yaitu lempung halus, mengandung $17-35 \%$ liat serta lempung berliat, mengandung 37 - $55 \%$ liat. Derajat kemasaman tanah atau $\mathrm{pH}$ tanah dari sangat masam sampai masam (pH 4.1 - 4.8). Kandungan bahan organik yang tipis sebesar $8-12 \mathrm{~cm}$ pada lapisan atas tanah termasuk rendah hingga sedang dan pada lapisan bawahnya sebagian besar sangat rendah, dengan nilai perbandingan $\mathrm{C} / \mathrm{N}$ yang rendah (5 - 10). Sementara kandungan $P$ potensialnya sangat rendah dan $\mathrm{K}$ potensial yang bervariasi, dari sangat rendah hingga rendah, baik pada lapisan tanah bagian atas maupun lapisan tanah bagian bawah. Selain itu, jumlah basa - basa yang dapat tukar juga tergolong sangat rendah pada seluruh lapisan, kecuali pada lapisan umumnya rendah. Ion $\mathrm{K}$ hanya berkisar antara 0.00 sampai $0.1 \mathrm{cmol} \mathrm{kg}^{-1}$ tanah. Pada semua lapisan tanah, nilai Kapasitas Tukar Kation (KTK) tanah termasuk rendah maupun nilai Kejenuhan Basa (KB) tanah sebagian besar sangat rendah yakni $20 \%$ atau kurang (Pusat Penelitian dan Pengembangan Tanah dan Agroklimat, 2005).

Secara umum tanah Ultisol sangat menunjang dalam proses pemupukan karena memiliki KTK yang sedang sampai tinggi (> 16 $\mathrm{cmol} / \mathrm{kg}$ ). Tanah ultisol memiliki potensi sebagai media yang baik untuk pertumbuhan tanaman karena memiliki penampang tanah yang cukup dalam. Kondisi penampang tanah dengan KTK sedang sampai tinggi menyebabkan tanah Ultisol dapat dimanfaatkan untuk budidaya berbagai jenis tanaman. Tetapi dalam upaya pengembangan pertanian, tanah Ultisol ternyata memiliki beberapa kendala, yakni kemasaman dan kejenuhan aluminium tinggi, kandungan hara rendah, kandungan bahan organik yang rendah serta peka erosi. Tetapi, kendala tersebut masih dapat teratasi melalui penerapan teknologi pemupukan, pengapuran dan pengelolaan bahan organik (Prasetyo, 2006). 
Agroradix Vol. 3 No.2

ISSN : 2621-0665

\section{POTENSI LIMBAH PERTANIAN dan KOTORAN TERNAK SEBAGAI BIOCHAR}

Provinsi Sulawesi Tenggara terletak di jazirah Tenggara Pulau Sulawesi. Secara geografis terletak di bagian Selatan Garis Khatulistiwa, memanjang dari Utara ke Selatan di antara $02^{\circ} 45^{\prime}-06^{\circ} 15^{\prime}$ Lintang Selatan dan membentang dari Barat ke Timur di antara $120^{\circ} 45^{\prime}-124^{\circ} 45^{\prime}$ Bujur Timur. Provinsi Sulawesi Tenggara $25,75 \%$ atau $38.140 \mathrm{~km}^{2}$ merupakan wilayah daratan, mencakup jazirah tenggara pulau sulawesi dan beberapa pulau kecil. Secara keseluruhan, luas daratan Provinsi Sulawesi Tenggara mencapai 3.814.000 ha, Sebagian besar merupakan/digunakan sebagai hutan negara, penggunaan lahan diklasifikasikan ke dalam beberapa kategori yaitu; sawah, tanah pekarangan, tanah tegal/ kebun, tanah ladang, dll (BPS Provinsi Sulawesi Tenggara, 2013). Selanjutnya Sulawesi Tenggara merupakan daerah yang memiliki potensi sumberdaya alam khususnya pertanian, tetapi upaya pemanfaatan maupun pengembangan biochar sebagai bahan pembenah tanah masih jarang atau belum dilakukan, sementara bahan dasar biochar dalam bentuk biomassa atau sisa-sisa hasil panen tanaman maupun sisa-sisa kotoran hewan sangat banyak tersedia, misalnya ampas sagu, jerami padi dan pupuk kandang. Ampas sagu ialah limbah hasil pertanian berasal dari jaringan tanaman yang mengandung hara penting untuk tanaman (Armadan et al., 1997). Menurut Sulistyowati (2011) bahwa bokasi ampas sagu mengandung C-Organik yang cukup tinggi (52,62\%).

Salah satu sumber bahan organik ialah pupuk kandang (Wardah, 2014). Sudiarso (2007) menyatakan bahwa pupuk kandang sapi segar (kotoran sapi yang belum mengalami dekomposisi) mengandung 0.92\% $\mathrm{N}, \quad 0.43 \% \mathrm{P}$ dan $0.54 \% \mathrm{~K}$, setelah terdekomposisi anaerob selama 10 minggu mengandung $1.52 \% \mathrm{~N}, 0.71 \% \mathrm{P}$ dan $0.79 \% \mathrm{~K}$, selanjutnya pupuk kandang hasil dekomposisi aerob mengandung $1.14 \% \mathrm{~N}, 0.57 \% \mathrm{P}$ dan $0.67 \%$ K. Aplikasi bahan organik ke dalam tanah melalui pupuk kandang maupun limbah hasil panen pertanian dapat meningkatkan kandungan $\mathrm{N}$ dan $\mathrm{C}$ tanah (Fliebbach et al., 2007).

Jerami padi ialah limbah pertanaman padi, mudah diperoleh dan umumnya petani melakukan pembakaran jerami padi setelah panen, berdampak pada pencemaran lingkungan. Hasil pengujian BPTP Kalimantan Timur (2011) menunjukkan bahwa kompos jerami padi mengandung $\mathrm{pH}(6,86)$, Kadar Air $(35,83 \%), C(35,83 \%), N(1,57 \%), P(0,02 \%)$, Fe $(4,04 \mathrm{ppm})$ Zn $(0,09 \mathrm{ppm})$ dan KTK $(6,62$ $\mathrm{cmol} / \mathrm{kg})$. Jerami padi dapat dimanfaatkan kembali sebagai sumber pupuk yang ramah lingkungan, selanjutnya pemanfaatan limbah jerami padi sebagai bahan organik dapat memberikan dampak positif dalam perbaikan kesuburan tanah, utamanya kondisi fisik tanah (Nurhayati et al., 2011). Meskipun proses dekomposisi jerami padi dalam tanah membutuhkan waktu lama, tetapi memiliki potensi sebagai bahan dalam pembuatan biochar.

\section{SYARAT TUMBUH DAN POLA PERTUMBUHAN KACANG TANAH \\ Syarat Tumbuh}

Kacang tanah dapat dibudidayakan pada ketinggian tempat $0-1500$ meter di atas permukaan laut. Suhu $\pm 20-30^{\circ} \mathrm{C}$ merupakan suhu optimal untuk perkecambahan benih, suhu $24-27^{\circ} \mathrm{C}$ (suhu udara) dan $27-30^{\circ} \mathrm{C}$ (suhu tanah) merupakan suhu optimal untuk pertumbuhan kacang tanah, sementara suhu $\quad \pm 30-34^{\circ} \mathrm{C}$.merupakan suhu ideal untuk pertumbuhan ginofor. Curah hujan yang dikehendaki kacang tanah yakni 900 $2000 \mathrm{~mm}$ per tahun. Kacang tanah dapat dibudidayakan pada berbagai jenis tanah. Tanaman kacang tanah dapat dibudidayakan di berbagai lingkungan agroklimat, dengan beragam suhu, curah hujan maupun jenis tanah. Umumnya jenis lahan pada lahan sawah, yaitu Aluvial dan Regosol, sementara pada lahan kering yaitu Podzolik Merah Kuning dan Latosol (Rahmianna et.al., (2015).

Kacang tanah sangat sesuai di tanam pada tanah bertekstur ringan yakni tanah yang termasuk dalam kategori tekstur lempung berpasir (sandy loam), pasir berlempung (loamy sand), lempung liat 
berpasir (sandy clay loam), mempunyai struktur tanah remah dan gembur serta berwarna cerah pucat. Mayoritas kacang tanah di Indonesia, dibudidayakan pada beberapa jenis tanah misalnya tanah ordo Alfisol, Entisol, Inceptisol dan sebagian kecil pada ordo Oxisol dan Ultisol (Taufiq, 2014). Tingkat kemasaman tanah optimal bagi pertumbuhan kacang tanah ialah $\mathrm{pH} \mathrm{5,0} \mathrm{-} \mathrm{6,5.}$ Tanah yang gembur dan berstruktur ringan akan memudahkan ginofor masuk ke dalam tanah, sehingga secara optimal akar maupun polong dapat berkembang serta memudahkan saat panen (Yurnalis, 2006). Selain itu, kacang tanah menghendaki lahan gembur agar ginofor mudah menembus tanah dan kaya unsur hara seperti $\mathrm{Ca}, \mathrm{N}, \mathrm{P}$ dan $\mathrm{K}$ serta pH 5 - 6.3. (Aziz et al., 2013).

\section{Pola Pertumbuhan Kacang Tanah}

Kacang tanah (Arachys hypogaea L.) termasuk dalam family Papilionidae, subfamily Leguminosae, genus Arachis. Kacang tanah ialah tanaman herba semusim dengan akar tunggang dan akar - akar lateral berkembang baik. daunnya terdiri dari $3-4$ helaian disebut tetra foliate, berbentuk bulat, elips dan agak lancip, mempunyai daun penumpu, bentuk bunganya seperti kupukupu, buah atau polong tumbuh dan berkembang di dalam tanah (berisi 1 - 4 biji per polong).

Kacang tanah bersifat indeterminit, dicirikan oleh tetap tumbuhnya bagian vegetatif pada saat tanaman sudah mulai memasuki pertumbuhan generatif. Varietas Spanish yang banyak di tanam di Indonesia memiliki periode vegetatif yakni 60 - 80 hari. Menurut Trustinah (1993) bahwa pola pertumbuhan kacang tanah dikelompokkan dalam 2 kelompok, yakni pola vegetatif dan pola reproduktif. Pertumbuhan vegetatif kacang tanah dimulai sejak perkecambahan sampai awal pembungaan yaitu umur 25 - 31 HST (Hari Setelah Tanam) . Pola pertumbuhan vegetatif kacang tanah mencakup empat stadia, yaitu :

1. Stadia awal pertumbuhan atau stadia juvenile, dicirikan oleh pertumbuhan yang lambat, terjadi sejak berkecambah sampai umur $20-25$ HST.

2. Stadia pemacuan pertumbuhan, dicirikan oleh adanya penambahan bobot biomassa yang cepat, terjadi sejak umur \pm 26 - 75 HST.

3. Stadia biomassa konstan, dicirikan oleh tidak terjadinya penambahan bobot tajuk tanaman, terjadi sejak umur $\pm 75-110$ HST.

4. Stadia peluruhan, dicirikan oleh bobot biomassa (tajuk tanaman) semakin berkurang sebagai akibat dari daun mulai berguguran serta tidak terdapatnya daun baru yang terbentuk, terjadi sejak umur \pm 100 HST sampai tanaman mati.

Penandaan fase refroduktif didasarkan pada terbentuknya bunga, buah dan biji. Fase produktif kacang tanah mencakup delapan stadia, yaitu :

1. Stadia pembungaan. Pembungaan kacang tanah dimulai sejak umur 27 - 32 HST, dicirikan oleh telah munculnya bunga pertama. Total bunga yang terbentuk setiap hari akan mengalami peningkatan sampai maksimal dan menurun selama mendekati pengisian polong. Bunga yang dihasilkan tidak semuanya menjadi polong tua, hanya $\pm 10-20 \%$ dari bunga yang berkembang dan muncul pada awal stadia pembungaan.

2. Stadia pertumbuhan ginofor. Ginofor atau tangkai kepala putik, muncul pada hari keempat atau kelima saat bunga mekar kemudian akan memanjang serta menuju tanah dan memulai pembentukan polong. Seluruh bunga yang dihasilkan $\pm 55 \%$ yang menjadi ginofor.

3. Stadia polong terbentuk. Terbentuknya polong ialah saat ujung ginofor sudah mulai membengkak, yakni saat umur 40 HST sampai 45 HST.

4. Stadia pengisian polong. Polong penuh dicapai saat umur 44 HST - 52 HST. Pada keadaan ini polong masih 
Agroradix Vol. 3 No.2

ISSN : 2621-0665

berwarna putih dengan guratan pada kulit polong bagian luar belum nampak.

5. Stadia pembentukan biji. Pembentukan biji dimulai setelah mencapai ukuran maksimum yaitu umur 52 HST sampai 57 HST.

6. Biji penuh. Biji penuh dicapai antara umur 60 HST sampai 68 HST. Pada stadia pembentukan biji dan biji penuh warna kulit polong bagian luar berubah menjadi kuning kecoklatan dan guratannya sudah mulai jelas dan permukaannya sudah kasar.

7. Proses pemasakan biji. Proses pemasakan biji dimulai antara umur 68 HST sampai 75 HST. Keadaan ini dicirikan dengan warna polong semakin gelap dan guratan pada polong sudah semakin nyata.

8. Stadia biji. Biji masak penuh dicapai saat umur 85 HST dan pada umur lebih lanjut akan didapatkan perubahan misalnya bobot biji semakin meningkat dan bintil - bintil hitam yang semakin jelas di kulit bagian dalam.

\begin{tabular}{|c|c|c|}
\hline $\begin{array}{l}\text { Pemanfaatan } \\
\text { Perbaikan }\end{array}$ & $\begin{array}{l}\text { Teknologi } \\
\text { Kesuburan }\end{array}$ & $\begin{array}{r}\text { Biochar } \\
\text { Tanah }\end{array}$ \\
\hline & & \\
\hline
\end{tabular}
menyatakan bahwa biochar ialah bahan yang berasal dari biomassa dalam bentuk sisa hasil pengolahan tanaman yang selanjutnya dipanaskan dalam suatu wadah sedikit maupun tanpa oksigen. Aplikasi biochar ke dalam tanah memiliki potensi meningkatkan kandungan ketersediaan C dalam tanah, kemampuan menahan air maupun unsur hara di dalam tanah yang penting bagi tanaman (Mawardiana et al., 2013).

\section{Peran Biochar}

Biochar (biomass + charcoal) bukan merupakan pupuk melainkan bahan pembenah tanah (soil amendement) yang mampu memperbaiki kemampuan tanah, misalnya dalam menahan air dan mengurangi kehilangan unsur hara. Apliaksi biochar sebagai suatu alternatif pembenah tanah dapat meningkatkan kualitas tanah (Gani, 2009). Fungsi biochar sebagai amendement tanah disebabkan struktur biochar yang sangat porous, sehingga dapat menyimpan air dan meningkatkan area permukaan tanah. Menurut Glauser et al., (2002) bahwa fungsi biochar sebagai pembenah tanah dapat memberikan efek baik melalui perbaikan sifat fisik tanah, biologi tanah dan kimia tanah dengan memasok sejumlah nutrisi yang penting bagi tanaman sehingga akan meningkatkan pertumbuhan tanaman.

Aplikasi biochar pada tanah dapat memperbaiki struktur tanah, porositas tanah, distribusi ukuran partikel tanah sehingga akan memperbaiki tata udara tanah, kapasitas menyimpan air dan meningkatkan status hara dan mikrobia pada rizospir (Amonette dan Joseph, 2009). Selanjutnya, Novak et al. (2009) menyatakan bahwa sebagian besar amandemen tanah bukan pupuk, namun memiliki kemampuan untuk mempertahankan sejumlah nutrisi yakni $\mathrm{P}, \mathrm{K}$ dan $\mathrm{Ca}$ serta setiap saat akan melepaskan hara dengan baik ke dalam tanah. Kualitas biochar sangat ditentukan dari bahan baku maupun melalui proses pembakaran (Sohi et al., 2010). Aplikasi biochar di dalam tanah, menyediakan habitat bagi mikroba tanah. Secara umum biochar yang telah diaplikasikan dapat bertahan dalam tanah selama ratusan bahkan ribuan tahun, serta tidak mengganggu keseimbangan $\mathrm{C}$ dan $\mathrm{N}$ tanah dalam jangka waktu panjang, namun sebaliknya biochar memiliki kemampuan menahan dan menjadikan air serta nutrisi lebih tersedia bagi tanaman.

Umumnya biochar dihasilkan melalui pirolisis. Pirolisis ialah proses di mana suhu di dorong untuk mendekomposisi biomassa tanpa pembakaran. Pada sistem pirolisis, biochar yang dihasilkan sebagian besar dalam keadaan tanpa oksigen dan paling sering dengan sumber panas dari luar. Bahan dasar yang digunakan dalam pirolisis dapat berupa berbagai jenis dan bentuk biomassa. Menurut Gani (2009) bahwa pemanfaatan biochar ke dalam tanah memiliki pengaruh yang positif utamanya dalam upaya mengurangi emisi maupun membantu menambah upaya 
Agroradix Vol. 3 No.2

ISSN : 2621-0665

pengikatan gas rumah kaca di atmosfer maupun melalui peningkatan kesuburan tanah maupun peningkatan produksi tanaman. Residu biomassa pertanian dapat dimanfaatkan menjadi biochar, misalnya tongkol jagung, kulit buah leguminosae, sekam padi, tempurung kelapa, limbah industri tebu serta residu biomassa kehutanan misalnya potongan kayu, kulit kayu, sisa - sisa usaha perkayuan dan bahan organik daur ulang lainnya (Yaman, 2004 ; Lehmann et al., 2006)

Lehmann et al., (2006) menyatakan bahwa dalam proses pembuatan biochar akan dihasilkan $50 \%$ C, sementara dekomposisi biologi umumnya hanya meninggalkan kurang dari 20\% C setelah 5 - 10 tahun kemudian, sedangkan melalui proses pembakaran hanya meninggalkan $3 \% \mathrm{C}$. Berbagai cara pembuatan biochar telah tersedia mulai dari yang tradisional sampai yang paling maju. Aplikasi biochar pada tanah dapat memberikan dampak positif terhadap perubahan fisik dan kimia tanah. Hal ini disebabkan tingginya luas permukaan spesifik biochar maupun adanya penambahan unsur hara secara langsung serta kandungan bahan organik sebagai bahan baku biochar. Hal ini telah dilaporkan Glaser et al., (2002) bahwa setelah aplikasi biochar terjadi peningkatan retensi hara dan ketersediaan hara. Kenyataan bahwa bahan organik tanah pada tanah yang kurang subur sangat rendah, maka teknologi yang paling sederhana untuk memperbaiki produktivitas tanah dan menstabilkan panen ialah dengan penambahan amandemen organik (Islami et al., 2011).

$$
\text { Pengaruh biochar terhadap }
$$

produktivitas tanaman tergantung pada jumlah dan bahan yang ditambahkan. Hal ini sesuai dengan pernyataan Gani (2010) bahwa peningkatan produktivitas tanaman dapat dipengaruhi oleh jumlah biochar yang ditambahkan ke dalam tanah. Lehman et al., (2003) menyatakan bahwa dengan bertambahnya jumlah dosis biochar, menyebabkan tanaman dapat memiliki respon positif sampai dicapainya tingkat maksimum pada daerah tertentu.
Beberapa hasil penelitian sebelumnya khususnya pada jenis tanah dengan tingkat kesuburan tanah rendah menunjukkan perbaikan kondisi kesuburan tanah baik secara fisik, kimia dan biologi tanah setelah diaplikasikan biochar. Hasil penelitian Yamato et al. (2006) menunjukkan bahwa aplikasi biochar dari kayu akasia ditambah pupuk, dapat meningkatkan hasil kacang tanah.

\section{KESIMPULAN}

1. Pemanfaatan limbah pertanian serta kotoran hewan memiliki potensi besar sebagai biochar atau arang hayati tahan pelapukan di Sulawesi Tenggara.

2. Teknologi biochar memiliki potensi meningkatkan kandungan ketersediaan carbon dalam tanah, memperbaiki kemampuan tanah dalam menahan air dan mengurangi kehilangan unsur hara.

3. Aplikasi teknologi biochar dapat memberikan efek baik melalui perbaikan sifat fisik tanah, biologi tanah dan kimia tanah dengan memasok sejumlah nutrisi yang penting bagi pertumbuhan dan peningkatan hasil panen tanaman kacang tanah.

\section{DAFTAR PUSTAKA}

Amonette J.E. and S. Joseph. 2009. Characteristic of biochar : Microchemical properties. In : Lehman J. and Joseph S. (eds). Biochar for Environmental Management. Sci. and Tech. , Earthscan. London, UK. p. 33 - 52.

Armadan L. dan Sabri. 1997. Pemanfaatan Ampas Sagu dan Pupuk Kandang Sebagai Alternatif Pengganti Kapur dalam Memperbaiki Sifat Kimia Tanah Podsolik Merah Kuning. Skripsi Fakultas Pertanian Universitas Haluoleo. Kendari. (Unpublish).

Azis A. B.A. Bakar dan A.A. Rahmianna. 2013. Keragaan Beberapa Varietas Unggul Kacang Tanah di Lahan Gambut Provinsi Aceh. Prosiding Seminar Nasional Hasil Penelitian Tanaman Aneka Kacang dan 
Umbi Tahun 2013. Pusat Penelitian dan Pengembangan Tanaman Pangan Badan Penelitian dan Pengembangan Pertanian, Bogor 2014. h. 327.

Badan Pusat Statistik Provinsi Sulawesi Tenggara, 2013. Sulawesi Tenggara Dalam Angka. BPS Sulawesi Tenggara. $458 \mathrm{Hal}$.

BPS. 2015. Tanaman Pangan. Available at http://bps.go.id/tnmn pgn.php

BPTP Kaltim, 2011. Leaflet Pemanfaatan Limbah Pertanian (Jerami Padi) Sebagai Bahan Organik Dengan Menggunakan Tricholant. Balai Pengkajian Teknologi Pertanian Kalimantan Timur. Litbang Kementan. h. 11 - 13.

Fliebbach A. H. Oberholzer. L. Gunst and P. Mader. 2007. Soil Organic Matter and Biological Soil Quality Indicators After 21 Years of Organic and Conventional Farming. Agriculture, Ecosystem and Environ. 118 : 273 - 284.

Gani A. 2010. Multiguna Arang - Hayati Biochar. Sinar Tani Edisi 13 - 19 Oktober 2010.

Gani, A. 2009. Potensi Arang Hayati "Biochar" Sebagai Komponen Teknologi Perbaikan Produktivitas Lahan Pertanian. Iptek Tanaman Pangan. 4 (1) : 33 - 48.

Glaser B. J. Lehmann, C. Steiner, T. Nehls, M. Yousaf and W. Zech. 2002. Potential of Pyrolyzed Organic Matter in Soil Amelioran. $12^{\text {th }}$ ISCO Conference. Beijing.

Glaser B., J, Lehmann and W. Zech. 2002. Ameliorating Physical and Chemical Properties af Highly Weathered Soils in the Tropics with Charcoal a Rev. Biol. and Fertility of Soil. $35: 219$ - 230.

Hartatik W. dan Setyana, 2012. Ameliorasi dan Pemupukan untuk Peningkatan dan Produktivitas Kedelai.di Lahan Suboptimal. Prosiding Seminar Nasional Teknologi Pemupukan dan Pemulihan Lahan Terdegradasi. Badan Penelitian dan Pengembangan Pertanian. Kementerian Pertanian.
Isa, A., F.S. Zauyah, dan G. Stoops. 2004. Karakteristik Mikromorfologi TanahTanah Volkanik di Daerah Banten. J. Tanah dan Iklim $22: 1$ - 14 .

Islami T, B. Guritno. N. Basuki dan A. Suryanto. 2011. Biochar For Sustaining Productivity of Cassava Based Cropping Systems in the Degraded Lands of East Java, Indonesia. J. Trop. Agric. 49 (1-2) : 40 46.

Lehman, J. and M. Rondon, 2006. Biochar Soil Management on Highly Weathered Soil in the Humid Tropics. 517 - 530 in Biological Approaches to Sustainable Soil System (Norman Upholf et al Eds).Taylor \& Francis Group PO BOX 409267 Atlanta, GA 30384-9267.

Lehmann J. and S. Joseph. 2009. Biochar for Enfironmental Management Science and Technology. Earthscan in the UK and USA.

Lehmann J. JP da Silva Jr. C. Steiner. T. Nehls. W. Zech \& B. Glaser. 2003. Nutrient Availability and Leaching in an Archaeological Anthrosol and a Ferralsol of the Central Amazon Basin: Fertilizer, Manure and Charcoal Amendements. Plant and Soil. 249 : 343 357.

Lehmann, J. J. Gaunt, and M. Rondon, 2006. Biochar Sequestration in Terrestrial Ecosystem a Rev. Mitigation and Adaptation Strategies for Global Change. $11: 403$ - 427.

Mawardiana, Sufardi dan E. Husen. 2013. Pengaruh Residu Biochar dan Pemupukan NPK Terhadap Sifat Kimia Tanah dan Pertumbuhan serta Hasil Tanaman Padi Musim Tanam Ketiga. J. Konservasi Sumber Daya Lahan. $1(1)$ : $16-23$.

Mulyani A. 2006. Potensi Lahan Kering Masam untuk Pengembangan Pertanian. Warta Penelitian dan Pengembangan Pertanian. 28 (2) : 16 - 17.

Novak J.M. W.J. Busscher. D.L. Laird. M. Ahmedua. D.W. Watts. M.AS. Niandou. 
Agroradix Vol. 3 No.2

ISSN : 2621-0665

2009. Impact of Biochar Amendment on Fertility of a Southeastern Coastal Plain Soil. Soil Sci. 174 : 105 - 112.

Nurhayati. A. Jamil dan R.S. Anggraini. 2011. Potensi Limbah Pertanian sebagai Pupuk Organik Lokal di Lahan Kering Dataran Rendah Iklim Basah. J. Iptek Tanaman Pangan. (6) (2) : 193 - 202.

Prasetyo B.H. dan D.A. Suriadikarta. 2006. Karakteristik, Potensi dan Teknologi Pengelolaan Tanah Ultisol Untuk Pengembagan Pertanian Lahan Kering di Indonesia. J. Litbang Pertanian. 25 (2) : 39 - 47.

Prasetyo, B.H., D. Subardja, dan B. Kaslan. 2005. Ultisols dari Bahan Volkan Andesitic di Lereng Bawah G. Ungaran. J. Tanah dan Iklim $23: 1-12$.

Pusat Penelitian dan Pengembangan Tanah dan Agroklimat. 2005. Teknologi Pengelolaan Lahan Kering; Menuju Pertanian Produktif dan Ramah Lingkungan. Badan Penelitian dan Pengembangan Pertanian. Departemen Pertanian. Edisi kedua. $245 \mathrm{~h}$.

Rahmianna, A.A. Pratiwi, H. dan Harnowo, D. 2015. Budidaya Kacang Tanah. Balai Penelitian Tanaman Aneka Kacang dan Umbi. Monograf Balitkabi No. 13. Hal 133169.

Raja B.S.L., B.S.J. Damanik dan J. Ginting. 2013. Respon Pertumbuhan dan Produksi Kacang Tanah Terhadap Bahan Organik Tithonia diversifolia dan Pupuk SP-36. J. Online Agroekoteknologi Universitas Sumatera Utara. 1 (3) : 725 - 731.

Sohi S.P. E. Krull. E. Lopez Capel and R. Bol. 2010. A Rev. of Biochar and Its Use and Function in Soil. ADVANCES IN AGRONOMY. 105 : 47 - 82.

Sudiarso. 2007. Pupuk Organik dalam Sistem Pertanian Berkelanjutan. Fakultas Pertanian Universitas Brawijaya. Malang. Cetakan Pertama. $264 \mathrm{~h}$.

Sulistyowati S, 2011. Pemberian Bokashi Ampas Sagu Pada Medium Aluvial Untuk
Pembibitan Jarak Pagar. J. Tek. Perkebunan \& PSDL. $1: 8$ - 12 .

Sutanto. 2002. Penerapan Pertanian Organik, Pemasyarakatan dan Pengembangannya. Penerbit Kanisius. Yogyakarta.

Taufiq A. 2014. Identifikasi Masalah Keharaan Tanaman Kacang Tanah. Kementerian Pertanian. Balai Penelitian Tanaman Aneka Kacang dan Umbi, Malang. h. 6 - 7.

Taufiq A. dan Kristono, A. 2015. Keharaan Tanaman Kacang Tanah. Balai Penelitian Tanaman Aneka Kacang dan Umbi. Monograf Balitkabi No. 13. Hal. 170 - 193.

Trustinah, 1993. Biologi Kacang Tanah. Badan Penelitian dan Pengembangan Pertanian. Pusat Penelitian dan Pengembangan Tanaman Pangan. Balai Penelitian Tanaman Pangan, Malang. Monograf Balittan Malang (12): h. $9-14$.

Wardah L. 2014. Perbaikan Kesehatan Tanah dengan Penambahan Pupuk Kandang Sapi dan Kompos Serasah Untuk Tanaman Kacang Tanah (Arachis hypogaea L.) di Desa Leranwetan, Palang, Tuban. Tesis Program Pasca Sarjana Fakultas Pertanian Universitas Brawijaya, Malang. (Unpublish).

Yaman S. 2004. Pyrolysis of Biomass to Produce Fuels and Chemical Feedstocks. Energy Conversion and Management. 45 : $651-671$.

Yamato M. Y. Okimori. I.F. Wibowo. S. Anshori and M. Ogawa. 2006. Effect of the Application of Charred Bark of Acacia mangium on the Yield of Maize, Cowpea and Peanut and Soil Chemical Properties in South Sumatra, Indonesia. J. Soil Sci. Plant Nutr., 52 : 489 - 495. Eugenia. 10 (1) : 1-7.

Yurnalis. 2006. Pengaruh Aplikasi Pupuk Organik dan Pupuk An Organik Terhadap Pertumbuhan, Produksi serta Mutu Benih Kacang Tanah. Thesis Institut Pertanian Bogor. 